\begin{abstract}
Б.Н. Латыпов
Развитие частновладельческих горных заводов Уфимской губернии в условиях экономического кризиса начала XX века
\end{abstract}

doi:10.31518/2618-9100-2021-5-5

УДК 94(470.57)

Выходные данные для цитирования:

Латыпов Б.Н. Развитие частновладельческих горных заводов Уфимской губернии в условиях экономического кризиса начала XX века // Исторический курьер. 2021. № 5 (19). С. 55-63. URL: http://istkurier.ru/data/2021/ISTKURIER-2021-505.pdf
B.N. Latypov*

\section{The Development of Private Mining Factories in Ufa Province in the Context of the Economic Crisis at the Beginning of the $20^{\text {th }}$ Century}

doi:10.31518/2618-9100-2021-5-5

How to cite:

Latypov B.N. The Development of Private Mining Factories in Ufa Province in the Context of the Economic Crisis at the Beginning of the $20^{\text {th }}$ Century // Historical Courier, 2021, No. 5 (19), pp. 55-63. [Available online: http://istkurier.ru/ data/2021/ISTKURIER-2021-5-05.pdf]

Abstract. The article is devoted to a relatively little-studied aspect of the history of privately owned mining plants of the Ufa province during the economic crisis of 1900-1903. The economic indicators of the Avzyan-Petrovsk, Kaginsk, Katav-Ivano, Lemezinsk, Uzyansk, Ust'-Katavsk and Yuryuzan'-Ivanovsk plants are presented. The role of the owner of the Katav-Ivanovsk, Ust'-Katavsk and Yuryuzan'-Ivanovsk plants of Prince K.E. Belosel'skiy-Belozerskiy, whose plants continued to operate at the expense of subsidies allocated by the State Bank of the Russian Empire, is emphasized. In this study, an attempt is made to reveal the economic situation of privately owned mining plants of the Ufa province during of the economic crisis of 1900-1903. The dependence of iron smelting at privately owned mining plants on the economic crisis of the early $20^{\text {th }}$ century has been revealed. The influence of special measures of the government and banks on this industry is shown. In the conditions of the economic crisis, the process of corporatization of the mining industry accelerated. As a result of the economic crisis, work was stopped at the AvzyanPetrovsk and Lemezinsk plants, and the Uzyansk plant was closed. The reduction in effective demand of the population and investments led to a decline in production at mining plants, increased underutilization of production capacities and unemployment. The government has softened the economic crisis in industry with financial instruments. Indicators of financial and economic activity of mining plants clearly demonstrate the state of the plants at the beginning of the $20^{\text {th }}$ century.

Keywords: private mining factories; state bank of the Russian empire; capital; percent; metallurgical society; Ufa province; cast iron; economic crisis.

The article has been received by the editor on 15.03.2021.

Full text of the article in Russian and references in English are available below.

Аннотация. Статья посвящена сравнительно малоизученному аспекту истории частновладельческих горных заводов Уфимской губернии в период экономического кризиса 1900-1903 гг. Представлены экономические показатели деятельности Авзяно-Петровского, Кагинского, Катав-Ивановского, Лемезинского, Узянского, Усть-Катавского и ЮрюзаньИвановского заводов. Подчеркнута роль владельца Катав-Ивановского, Усть-Катавского и Юрюзань-Ивановского заводов князя К.Э. Белосельского-Белозерского, заводы которого продолжали действовать за счет субсидий, выделенных Государственным банком Российской империи. В данном исследовании предпринята попытка раскрыть экономиче-

\footnotetext{
* Латыпов Булат Назирович, магистр истории, Государственное автономное учреждение науки Республики Башкортостан «Башкирская энциклопедия», Уфа, Россия, e-mail: LatypovBN@yandex.ru

Latypov Bulat Nazirovich, Master of History, State Autonomous Institution of Republic of Bashkortostan Scientific Publishing Complex “Bashkir Encyclopedia”, Ufa, Russia, e-mail: LatypovBN@yandex.ru
} 
ское положение частновладельческих горных заводов Уфимской губернии на фоне экономического кризиса 1900-1903 гг. Выявлена зависимость выплавки чугуна на частновладельческих горных заводах от экономического кризиса начала XX в. Показано влияние специальных мер правительства и банков на эту отрасль промышленности. В условиях экономического кризиса ускорился процесс акционирования горнозаводской промышленности. В результате экономического кризиса была остановлена работа на Авзяно-Петровских и Лемезинском заводах, закрыт Узянский завод. Сокращение платежеспособного спроса населения и инвестиций привело к спаду производства на горных заводах, увеличило недогрузку производственных мощностей и безработицу. Правительство финансовыми инструментами смягчило экономический кризис в промышленности. Показатели финансово-экономической деятельности горных заводов ярко демонстрируют состояние заводов в начале XX в.

Ключевые слова: частновладельческие горные заводы; Государственный банк Российской империи; капитал, процент; металлургическое общество; Уфимская губерния; чугун; экономический кризис.

Горнозаводская промышленность Южного Урала в начале XX в., как и вся российская экономика, испытала кризисные явления, что привело к резкому спаду производства. В наибольшей степени нуждается в изучении экономическое положение частновладельческих горных заводов Уфимской губернии в условиях экономического кризиса начала XX в. Актуальность темы диктуется необходимостью детализации опыта модернизации в Российской империи. Целью исследования является определение состояния частновладельческой горнорудной промышленности Уфимской губернии в кризисные 1900-1903 гг., эффективности политики преодоления кризисных явлений. Методологической основой исследования выступает теория модернизации, всеобщие принципы научного познания. Источниковой основой исследования явились статистические сведения по Уфимской губернии, своды экономических данных по губернии ${ }^{1}$, а также статистические материалы о фабриках, заводах и промышленных заведениях Уфимской губернии ${ }^{2}$ С начала XX в. они публиковались Уфимской губернской земской управой в «Сборнике статистических сведений по Уфимской губернии» в виде историко-статистических таблиц.

История горных заводов Уфимской губернии в начале XX в. получила широкое освещение в работах отечественных историков. Ими были рассмотрены различные аспекты: проблемы генезиса капитализма в промышленности России, классовая борьба пролетариата, исследованы вопросы акционирования и синдицирования горнозаводских округов в начале XX в., становление промышленности в специфических историко-экономических, этнодемографических условиях Южного Урала, формирование рабочих кадров, организация и условия труда рабочих, вопросы о вовлечении башкир и пришлых нерусских народов края в сферу горнозаводской промышленности, о позитивных и негативных последствиях интенсивного горнозаводского освоения края для судеб его народов ${ }^{3}$.

\footnotetext{
${ }^{1}$ Голубев П.А. Сборник статистических сведений по Уфимской губернии. Уфа, 1900. Т. 7: Свод экономических данных по губернии. Ч. 3: Историко-статистические таблицы.

${ }^{2}$ Милюков Л.Е., Медведев И.А. Сборник статистических сведений по Уфимской губернии. Уфа, 1910. Т. 10. Фабрики, заводы и промышленные заведения Уфимской губернии. Ч. 2.

${ }^{3}$ Красильников М.П. Экономическое положение Уфимского края и тенденции в его развитии. Уфа, 1918; Кулишер И.М. Очерки истории русской промышленности. Пг., 1922; Гессен Ю.И. История горнорабочих СССР. М., 1926-1929. Т. 2; Василевский В.С. Златоуст. Прошлое и настоящее заводов. Л., 1932; Сигов С.П. Очерки по истории горнозаводской промышленности Урала. Свердловск, 1936; Гиндин И.Ф. Государственный банк и экономическая политика царского правительства (1861-1892 гг.). М., 1960; Струмилин С.Г. Избранные произведения: История черной металлургии в СССР. М., 1967; Вяткин М.П. Горнозаводской Урал в 1900-1917 гг. М.; Л., 1965; Буранов Ю.А. Акционирование горнозаводской промышленности Урала (1861-1917). М., 1982; Гудков Г.Ф., Гудкова З.И. Из истории южноуральских горных заводов XVIII-XIX веков. Уфа, 1985-1993; Мударисов Р.3. Горнозаводская промышленность Южного Урала в первой половине ХІХ века. Уфа, 1998;
} 
Экономический кризис 1900-1903 гг. в России являлся, с одной стороны, частью мирового кризиса, а с другой - результатом промышленного прогресса. Мировой экономический кризис в России был глубже и продолжительнее, чем в Западной Европе и США. С наибольшей силой кризис поразил металлургическую отрасль промышленности. Как отмечает М.Г. Нечаев, «... в августе 1899 г. европейский финансовый кризис привел к резкому сокращению денежных потоков из-за рубежа и к существенным денежным стеснениям в России. Банки стали воздерживаться от кредитования предприятий, в том числе промышленных, повсеместно начал ощущаться недостаток свободных денежных средств» ${ }^{4}$.

Первые признаки финансового кризиса проявились в повышении учетного процента (процент, взимаемый банками при учете векселей) уже в 1899 г. В 1898 г. в Париже учетный процент повысился с 2,2 до 3,06 \%, в 1899 г. в Лондоне - с 3,26 до 3,75 \%, в Берлине - с 4,28 до 4,98 \%. С июня по декабрь 1899 г. в Российской империи Государственный банк повысил учетную ставку с 4,5 до 7 \%. Таким образом, фондовые ценности Российской империи, которые котировались на Парижской бирже, обрушились в цене к началу XX в. на 60 \%. Однако следует отметить, что к 1901 г. мировыми лидерами по производству стали становятся США и Германия ${ }^{5}$. Сталелитейная промышленность США в 1860-1900 гг. переживала период великого «взлета» в производстве ${ }^{6}$. Производство стали в США в 1860 году составляло 13 тыс. тонн, к 1900 году - 11412 тыс. тонн ${ }^{7}$.

В 1903 г. кризис на горных заводах Уфимской губернии достиг своего апогея. В январе 1903 г. в Екатеринбурге проходил ХІ съезд горнозаводчиков Урала, где участники признали, что горнозаводской Урал охвачен экономическим кризисом в очень острой форме и многие владельцы заводов близки к разорению. На съезде было отмечено, что на складах заводов накопились огромные запасы нераспроданной продукции, которые достигают на некоторых заводах годовой производительности. В результате промышленники вынуждены были реализовывать накопившийся металл ниже себестоимости ${ }^{8}$. В целях преодоления кризиса по инициативе министра финансов С.Ю. Витте Министерство финансов создало банковский синдикат во главе с Государственным банком, который скупал акции крупных предприятий, находившихся на грани банкротства. Некоторые предприятия и общества получили финансовую помощь ${ }^{9}$. Также при поддержке правительства большая часть государственных заказов была передана владельцам горных заводов.

Экономический кризис усиливал концентрацию производства и рабочей силы. Концентрация производства и капитала осуществлялась здесь, как и в других регионах Российской империи, в форме акционирования горных заводов. K началу XX в. из 9 горнозаводских округов края 5 были акционированы. В начале XX в. в Уфимской губернии действовали 23 металлургических предприятия, которые выпустили 12,8 млн пудов чугуна, 1,2 млн пудов железа, 4,3 млн пудов стали ${ }^{10}$. С наибольшей силой экономический кризис отразился на выплавке чугуна, размеры которой составляли в 1904 г. по отношению 1900 году лишь 79 \%, и с меньшей силой отразился на производстве различных видов железа и стали.

Кулбахтин Н.M. Горнозаводская промышленность Башкортостана в XVIII веке. Уфа, 2000; Гудкова 3.И. Предприниматели Южного Урала. Уфа, 2003; Алексеев В.В., Гаврилов Д.В. Металлургия Урала с древнейших времен до наших дней. М., 2008; История башкирского народа: в 7 т. Уфа, 2010. Т. 5; Нечаев М.Г. Экономический кризис 1900-1903 годов и его роль в развитии уральской промышленности // Вестник Пермского национального исследовательского политехнического университета. Социально-экономические науки. 2011. № 12. С. 103119; Неклюдов Е.Г. Горнозаводская промышленность в России второй половины XIX- начала XX в.: выбор организационной модели // Уральский исторический вестник. 2020. № 1 (66). С. 93-102.

${ }^{4}$ Нечаев М.Г. Экономический кризис 1900-1903 годов... С. 103-105.

${ }^{5}$ The World Book Encyclopedia. Chicago: A Scott Fetzer company, 1995. Vol. 10. P. 402.

${ }^{6}$ Rogers R.P. An economic history of the American steel industry. New York, 2009. P. 16.

${ }^{7}$ Ibid.

${ }^{8}$ Вяткин М.П. Горнозаводской Урал... С. 31.

${ }^{9}$ Нечаев М.Г. Экономический кризис 1900-1903 годов... С. 107.

${ }^{10}$ История башкирского народа... С. 23. 
$\mathrm{K}$ началу $\mathrm{XX}$ в. Катав-Ивановский завод, (рис. 1) основанный в 1757 г. И.Б. Твердышевым и И.С. Мясниковым ${ }^{11}$, производил рельсы. В 1900 г. завод функционировал с неполной загрузкой производственных мощностей. В 1903 г. неполная загрузка составляла $85 \%$, в 1904 г. - 79 \%. Нерентабельность производства способствовала появлению монополистических объединений.

В начале 70-х г. XIX в. Акционерное общество Белорецкие заводы, которое принадлежало Пашковым, было заложено в казну и выставлено на продажу. Оно было приобретено Московским торговым домом «Вогау и $\mathrm{K}^{0}$ », а в 1874 г. перешло в собственность вновь учрежденного Акционерного общества Белорецких железоде-

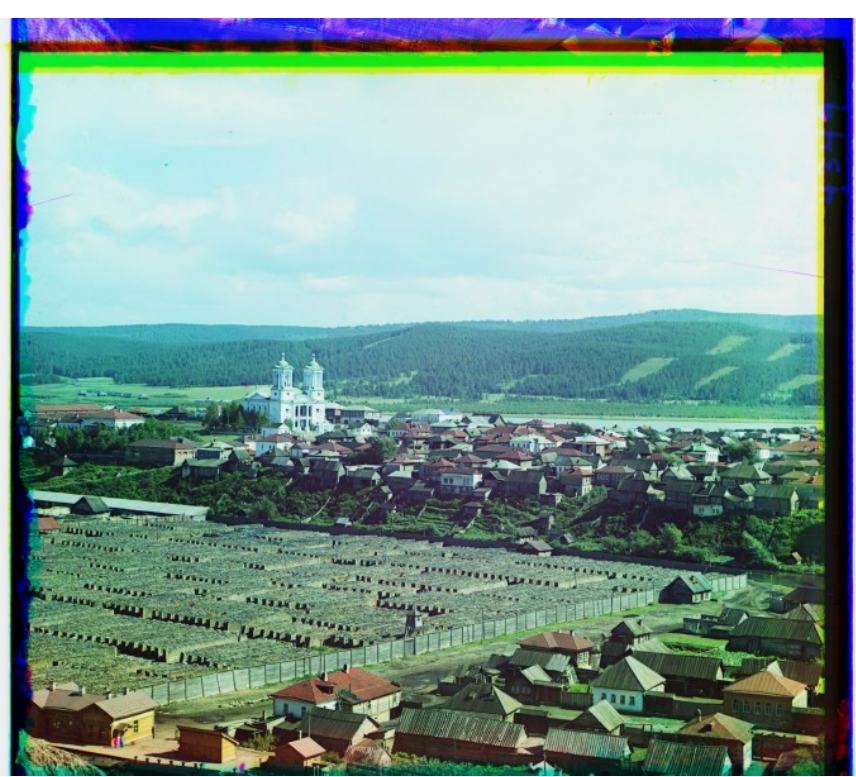

Puс. 1. Катав-Ивановский завод. Начало ХХ в. Фото С.М. Прокудина-Горского. лательных заводов Пашковых ${ }^{12}$. Акции Белорецких железоделательных заводов были распределены между участниками торгового дома «Вогау и $\mathrm{K}^{0}$ » таким образом, что фактически заводы остались в руках того же собственника, изменилась лишь форма собственности. В 1880-е г. к Белорецкому горному округу были присоединены приобретенные торговым домом «Вогау и $\mathrm{K}^{0}$ » Кагинский и Узянский заводы. В связи с долгами перед Государственным казначейством и Государственной сохранной казной в 1896 г. руководство общества требовало правительство увеличить акционерный капитал на 1750 тыс. руб. с помощью выпуска 7 тыс. акций по 250 руб. и при этом разрешить выпустить облигационный заем на 3 млн руб. облигациями в 500 и 1000 руб. из 5 \% годовых. Оба требования правительством были удовлетворены ${ }^{13}$.

Белорецкий горный округ представлял довольно большой интерес для торгового дома «Вогау и $\mathrm{K}^{0}$ », так как на его территории находилась гора Магнитная ${ }^{14}$. Таким образом, к началу XX в. основной капитал Акционерного общества Белорецких железоделательных заводов Пашковых составлял 3500 тыс. руб., которые были разделены на 14 тыс. акций. При этом увеличение основного капитала общества позволило в годы подъема укрепить положение заводов.

$\mathrm{B}$ начале $\mathrm{XX}$ в. Белорецкий горный округ являлся одним из крупнейших на Южном Урале. В 1899 году в горном округе было выплавлено 3288 тыс. пудов чугуна, прокатано 732 тыс. пудов железа и произведена 701 тыс. пудов литого металла. С наступлением экономического кризиса финансовое положение заводов изменилось. Хозяйственный год (1900-1901 гг.) был завершен с убытком в размере 237,5 тыс. руб. Задолженность перед торговым домом «Вогау и $\mathrm{K}^{0} »$ была 4300 руб., когда основной капитал составлял 3500 руб. Большая задолженность была связана с изменением профиля заводов. Владельцы заводов вынуждены были сократить выплавку чугуна и прокат железа, но при этом увеличить производство литого металла. В результате экономического кризиса снизились объемы выплавки чугуна.

В 1900 г. заводы Белорецкого горного округа произвели 3068 тыс. пудов, то в 1910 г. 1344 тыс. пудов. Из-за экономического кризиса в Белорецком горном округе был закрыт

\footnotetext{
${ }^{11}$ Кулбахтин Н.М. Катав-Ивановский завод // Башкирская энциклопедия: в 7 т. Уфа, 2007. Т. 3: 3-К. С. 368.

${ }^{12}$ Белорецких заводов общество // Башкирская энциклопедия: в 7 т. Уфа, 2005. Т. 1: А-Б. С. 429.

${ }^{13}$ Вяткин М.П. Горнозаводской Урал... С. 76.

${ }^{14}$ Буранов Ю.А. Акционирование горнозаводской промышленности Урала... С. 71.
} 
Узянский завод ${ }^{15}$. В результате активной деятельности торгового дома «Вогау и $\mathrm{K}^{0} »$ Белорецкие заводы в финансовом вопросе стали зависимы от капитала владельца.

В совершенно других условиях оказались Авзяно-Петровские и Лемезинский заводы. В начале XX в. заводы находились в собственности «Урало-Волжского металлургического общества», учрежденного в 1896 г. Парижским международным, Санкт-Петербургским международным, Санкт-Петербургским учетным и ссудными банками ${ }^{16}$. В 1900 г. АвзяноПетровские и Лемезинский заводы переходят к новому обществу «Комаровских железорудных месторождений и Южно-Уральских горных заводов». В годы экономического кризиса эти заводы работали в убыток. Росла большая задолженность по заработной плате перед рабочими. Расходы на содержание руководства с каждым годом увеличивались и в среднем составляли 8 копеек на пуд чугуна. В результате возник вопрос банкротства заводов, но Учетный комитет Государственного банка Российской империи разрешил Уфимскому отделению выделить кредит под залог металла 500 тыс. руб. ${ }^{17}$

В мае 1903 г. руководство «Комаровских железорудных месторождений и ЮжноУральских горных заводов общества» остановило работу Лемезинского завода и приняло решение к 1 июля остановить производство и на Авзяно-Петровских заводах, где была погашена одна из двух домен. Несмотря на все перипетии Лемезинский завод с нарастающими темпами выплавил чугуна в 1900 г. - 163 тыс. пудов; 1901 г. - 436 тыс.; 1903 г. - 205 тыс. пудов ${ }^{18}$. К началу 1904 г. общая задолженность составляла 1129 тыс. руб. Общая задолженность заводов Государственному банку Российской империи составила 1 млн руб., Парижскому международному банку по соло-векселям - 1119 тыс. руб.

В период экономического кризиса горные заводы князя Белосельского-Белозерского находились в тяжелом финансовом положении. В Уфимской губернии ему принадлежало наследственное имение Катав-Ивановское и селение Юрюзань-Ивановское (ЮрюзаньИвановский завод был основан в 1761 г. И.Б. Твердышевым и И.С. Мясниковым ${ }^{19}$ ). КатавИвановский завод с земельной площадью оценивался в 2020 тыс. руб. Юрюзань-Ивановский завод - в 1710 тыс. руб. Общая площадь заводов составляла 384 тыс. десятин, 350 тыс. десятин находилось под лесом. Численность рабочих заводов составляла около 10 тыс. чел. По территории заводов была проложена железнодорожная линия Златоустовской дороги. Уровень технической оснащенности и организации производства на заводах князя Белосельского-Белозерского был значительно ниже по сравнению с другими горными заводами. Большая часть двигателей были водяные, оставшаяся часть - паровые. Прокат в металлургии заводы вели весной, так как вначале было необходимо накопить в прудах весенние воды. Как известно, заводы Белосельского-Белозерского являлись привилегированными и пользовались поддержкой императоров Александра III и Николая II. В 1898 г. князь К.Э. Белосельский-Белозерский продал Усть-Катавский завод (рис. 2) «Южно-Уральскому металлургическому обществу» с общим капиталом в 6 млн франков, которые были разделены на 12 тыс. акций, из которых 2800 на сумму в 1400 тыс. франков было уплачено К.Э. Белосельскому-Белозерскому. Общая задолженность «Южно-Уральского металлургического общества» к 1 июля 1899 г. составляла 2 млн франков ${ }^{20}$. Бельгийские предприниматели Э. Диньефу, В. Пирло, Л.П. Пирло сохранили за собой только Усть-Катавский завод.

\footnotetext{
${ }^{15}$ Буранов Ю.А. Акционирование горнозаводской промышленности Урала... С. 159.

${ }^{16}$ Гудкова З.И. Урало-Волжское металлургическое общество // Башкирская энциклопедия: в 7 т. Уфа, 2010.

Т. 6: Советы народного хозяйства - У. С. 435-436.

${ }^{17}$ Вяткин М.П. Горнозаводской Урал... С. 78.

${ }^{18}$ Милюков Л.Е., Медведев И.А. Сборник статистических сведений по Уфимской губернии... С. 39.

${ }^{19}$ Голубев П.А. Сборник статистических сведений по Уфимской губернии... С. 20.

${ }^{20}$ Вяткин М.П. Горнозаводской Урал... С. 81.
} 
Стоит отметить, что заводы князя Белосельского-Белозерского все еще продолжали действовать за счет субсидий, выделенных Государственным банком Российской империи. Князь Белосельский-Белозерский неоднократно пытался заручиться поддержкой правительства, но банки не могли рисковать, не имея при этом никаких гарантий. Горные заводы могли давать прибыль лишь при условии постоянного финансирования и, кроме того, имели источники для компенсации замедленного оборота капитала. Финансирование большинства частновладельческих горных заводов происходило в хаотичном режиме, что приводило в итоге к диспропорциям.

Финансирование государством и банками заводов князя Белосельского-

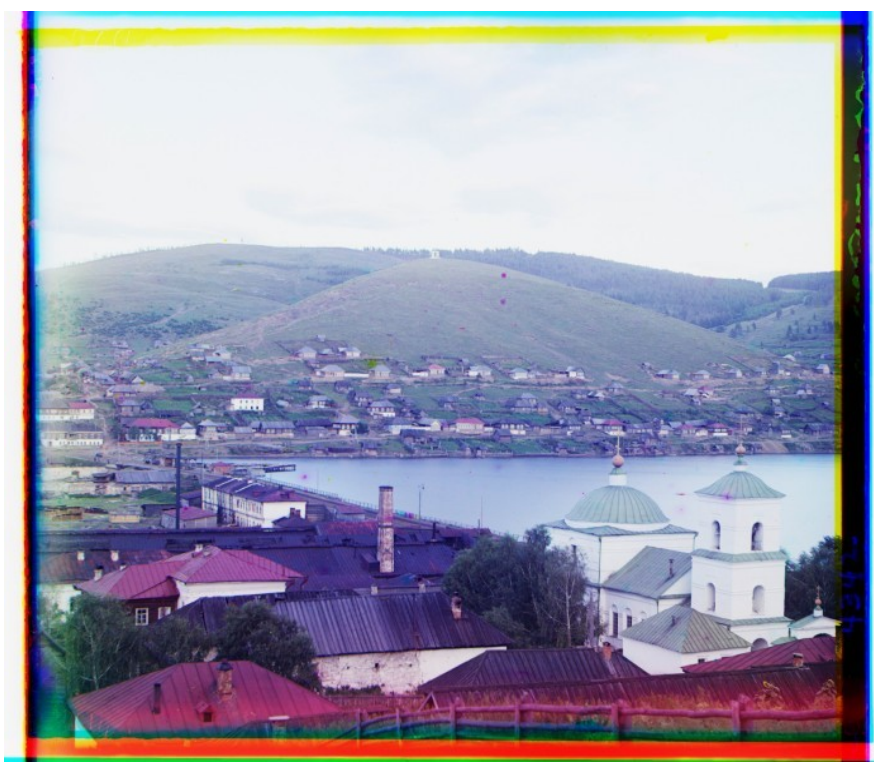

Рис. 2. Усть-Катавский завод.

Заводской пруд и Никольская гора. Начало XX в. Фото С.М. Прокудина-Горского.

Белозерского носило именно такой характер. По мнению Ю.А. Буранова, лишь крупные инвестиции могли обеспечить в новых условиях нарастающую прибыль ${ }^{21}$. В 1903 г. князь Белосельский-Белозерский приостановил договор с «Южно-Уральским металлургическим обществом». Заводы князя в дальнейшем действовали автономно. В 1903 г. над заводами князя Белосельского-Белозерского была установлена опека. При поддержке Николая II за князем сохранялись лишь земельные владения округа, но дальнейшее финансирование было прекращено ${ }^{22}$. В 1903 г. в журнале Комитета финансов приведено признание уфимского губернатора: «Хозяйство на заводах князя Белосельского-Белозерского уже давно велось не вполне правильно, в том смысле, что все свободные деньги постоянно требовались собственникам на личные расходы, и часто из-за этого настоятельнейшие потребности заводов по ремонту и улучшению постановки заводского дела не удовлетворялись, истребование же в Петербурге последних небольших оборотных средств завода, с трудом собранных одним из управляющих заводами в течение нескольких лет, побудило его оставить управление заводами» ${ }^{23}$.

Таким образом, начало XX в. являлось периодом финансовой нестабильности для частновладельческих горных заводов Уфимской губернии. Экономический кризис ускорил процесс акционирования горнозаводской промышленности. К началу XX в. из девяти горнозаводских округов края пять были акционированы. Промышленное производство России в период кризиса сократилось на 5 \%, выплавка чугуна уменьшилась на 15 \%, прокат рельсов - на $32 \%{ }^{24}$. Также сокращалась доля выплавки чугуна на частновладельческих горных заводах Уфимской губернии. В ходе экономического кризиса была остановлена работа на Лемезинском и Авзяно-Петровских заводах, закрыт Узянский завод. В результате сокращения платежеспособного спроса населения и инвестиций произошел спад производства на горных заводах, увеличилась недогрузка производственных мощностей и безработица. Одновременно правительство финансовыми инструментами смягчило экономический кризис в промышленности.

\footnotetext{
${ }^{21}$ Буранов Ю.А. Акционирование горнозаводской промышленности Урала... С. 99.

${ }^{22}$ Там же. С. 166.

${ }^{23}$ Вяткин М.П. Горнозаводской Урал... С. 84.

${ }^{24}$ Нечаев М.Г. Экономический кризис 1900-1903 годов... С. 105-106.
} 


\section{Лumepamypa}

Алексеев B.В., Гаврилов Д.В. Металлургия Урала с древнейших времен до наших дней. М.: Наука, 2008. 886 с.

Белорецких заводов общество // Башкирская энциклопедия: в 7 т. Уфа: Башк. энцикл., 2005. T. 1. А-Б. С. 429.

Буранов Ю.А. Акционирование горнозаводской промышленности Урала (1861-1917). М.: Наука, 1982. 261 с.

Василевский В.С. Златоуст. Прошлое и настоящее заводов. Л.: Тип. «Коминтерн», 1932. 70 c.

Вяткин М.П. Горнозаводской Урал в 1900-1917 гг. М.; Л.: Наука, 1965. 400 с.

Гессен Ю.И. История горнорабочих СССР. М.: Изд-во ЦК Союза горнорабочих, 19261929. T. 2.

Гиндин И.Ф. Государственный банк и экономическая политика царского правительства (1861-1892 гг.). М.: Госфиниздат, 1960. 415 с.

Голубев П.А. Сборник статистических сведений по Уфимской губернии. Издание Уфимской Губернской Земской Управы. Уфа: Типо-литография В.П. Калмацкого, 1900. Т. 7: Свод экономических данных по губернии. Ч. 3: Историко-статистические таблицы. 188 с.

Гудков Г.Ф., Гудкова З.И. Из истории южноуральских горных заводов XVIII-XIX веков. Уфа: Башк. кн. изд-во, 1985-1993.

Гудкова 3.И. Предприниматели Южного Урала. Уфа: Гилем, 2003. 215 с.

Гудкова 3.И. Урало-Волжское металлургическое общество // Башкирская энциклопедия: в 7 т. Уфа: Башк. энцикл., 2010. Т. 6: Советы народного хозяйства - У. С. 435-436.

История башкирского народа: в 7 т. / гл. ред. М.М. Кульшарипов. Уфа: Гилем, 2010. Т. 5. 468 c.

Красильников М.П. Экономическое положение Уфимского края и тенденции в его развитии. Уфа, 1918. 28 с.

Кулбахтин H.M. Горнозаводская промышленность Башкортостана в XVIII веке. Уфа: Китап, 2000. 280 с.

Кулбахтин Н.М. Катав-Ивановский завод // Башкирская энциклопедия: в 7 т. Уфа: Башк. энцикл., 2007. Т. 3. 3-К. С. 368.

Кулишер И.М. Очерки истории русской промышленности. Пг.: Тип. К.-О. Петрогубпрофсовета, 1922. 156 с.

Милюков Л.Е., Медведев И.А. Сборник статистических сведений по Уфимской губернии. Уфа: Издание Уфимской Губернской Земской Управы. Александровская улица д. Нагель: партиполит. Торгового дома. 1910. Т. 10: Фабрики, заводы и промышленные заведения Уфимской губернии. Ч. 2. 135 с.

Мударисов Р.3. Горнозаводская промышленность Южного Урала в первой половине ХІХ века. Уфа: Гилем, 1998. 171 с.

Неклюдов Е.Г. Горнозаводская промышленность в России второй половины XIX - начала XX в.: выбор организационной модели // Уральский исторический вестник. 2020. № 1 (66). С. 93-102.

Нечаев М.Г. Экономический кризис 1900-1903 годов и его роль в развитии уральской промышленности // Вестник Пермского национального исследовательского политехнического университета. Социально-экономические науки. 2011. № 12. С. 103-119.

Очерки по истории Башкирской АССР: в 2 т. / ред. А.П. Смирнов и др. Уфа: Башкнигоиздат, 1959. Т. 1. Ч. 2. 539 с.

Сигов С.П. Очерки по истории горнозаводской промышленности Урала. Свердловск: Свердлгиз, 1936. 292 с.

Струмилин С.Г. Избранные произведения: История черной металлургии в СССР. М.: Наука, 1967. 442 с. 
Rogers R.P. An economic history of the American steel industry. New York: Routledge, 2009. 224 p.

The World Book Encyclopedia. Chicago: A Scott Fetzer company, 1995. Vol. 10. 478 p.

\section{References}

Alekseyev V.V., Gavrilov D.V. (2008). Metallurgiya Urala s drevneyshikh vremen do nashikh dney [Ural Metallurgy from Ancient Times to Our Days]. Moscow, Nauka. 886 p.

Beloreckikh zavodov obschestvo (2005). [The Beloretsky Metallurgical Plant Society]. In Bashkirskaya entsiklopediya: $v 7$ t. T. 1: A-B [Bashkir Encyclopedia: in 7 vol. Vol. 1: A-B]. Ufa, Bashkir encyclopedia, p. 429.

Buranov, Yu.A. (1982). Aktsionirovanie gornozavodskoy promyshlennosti Urala (1861-1917) [Corporatization Mining Industry in Ural (1861-1917)]. Moscow, Nauka. 261 p.

Gessen, Y.I. (1926-1929). Istoriya gornorabochikh SSSR [History of Mining Workers of the USSR]. Moscow, Izd. CK Soyuza gornorabochikh. T. 2.

Gindin, I.F. (1960). Gosudarstvennyy bank i ekonomicheskaya politika carskogo pravitelstva (1861-1892 gg.) [The State Bank and the Eeconomic Policy of the Tsarist Government (18611892)]. Moscow, Gosfinizdat. 415 p.

Golubev, P.A. (1900). Sbornik statisticheskikh svedeniy po Ufimskoy gubernii. T. 7. Svod ekonomicheskikh dannykh po gubernii. Ch. 3. Istoriko-statisticheskaie tablitsy [The Collection of Sstatistical Information of Ufa Province. Vol. 7. The Set of Economic Data in the Province. Part 3. Historical and Statistical Ttables]. Ufa, The lithographic printing of V.P. Kalmacko. 188 p.

Gudkov, G.F., Gudkova, Z.I. (1985-1993). Iz istorii yuzhnouralskikh gornykh zavodov XVIII$X I X$ vekov [From the History of the South Ural Mining Plants of the $18^{\text {th }}-19^{\text {th }}$ Centuries]. Ufa, Bashk. kn. izd-vo.

Gudkova, Z.I. (2003). Predprinimateli Yuzhnogo Urala [Entrepreneurs of the Southern Urals]. Ufa, Gilem. 215 p.

Gudkova, Z.I. (2010). Uralo-Volzhskoe metallurgicheskoe obshhestvo [Uralo-Volzhskaya Metallurgical Society]. In Bashkirskaya entsiklopediya: $v \quad 7 \quad$ t. T. 6 . Sovety narodnogo khozyaystva - U. Ufa, Bashkir entsyklopedia, pp. 435-436.

Krasilnikov, M.P. (1918). Ekonomicheskoe polozhenie Ufimskogo kraya i tendentsii $v$ ego razvitii [The Economic Situation of the Ufa Region and Trends of the Ddevelopment]. Ufa. 28 p.

Kulbahtin, N.M. (2000). Gornozavodskaya promyshlennost Bashkortostana $v$ XVIII veke [Mining Industry of Bashkortostan in the $18^{\text {th }}$ Century]. Ufa, Kitap. 280 p.

Kulbakhtin, N.M. (2007). Katav-Ivanovskiy zavod [Katav-Ivanovskiy Plant]. In Bashkirskaya entsiklopediya: $v$ t t. T. 3. Z-K [Bashkir Encyclopedia: in 7 vol. Vol. 3. Z-K]. Ufa, Bashkir encyclopedia. p. 368.

Kulisher, I.M. (Ed.). (1922). Ocherki istorii russkoy promyshlennosti [Essays of the History of Russian Iindustry]. Petrograd, Tip. K.-O. Petrogubprofsoveta. 156 p.

Kulsharipov, M.M. (2010). Istoriya bashkirskogo naroda. [History of the Bashkir People]. Vol. V. Ufa, Gilem. 468 p.

Miljukov, L.E., Medvedev, I.A. (1910). Sbornik statisticheskikh svedeniy po Ufimskoy gubernii. T. 10: Fabriki, zavody i promyshlennye zavedeniya Ufimskoy gubernii. Ch. 2 [The Collection of Sstatistical Information of Ufa Pprovince. Vol. 10: Factories and Industrial Establishments of the Ufa Province]. Ufa, Trading house, 135 p.

Mudarisov, R.Z. (1998). Gornozavodskaya promyshlennost Yuzhnogo Urala v pervoy polovine $X I X$ veka [Mining Industry of the Southern Urals in the First Half of the $19^{\text {th }}$ Century]. Ufa, Gilem. $171 \mathrm{p}$.

Nechaev, M.G. (2011). Ekonomicheskiy krizis 1900-1903 godov i ego rol v razvitii uralskoy promyshlennosti [The Economic Crisis of 1900-1903 and its Role in the Development of the Ural Industry]. In Vestnik Permskogo natsionalnogo issledovatelskogo politekhnicheskogo universiteta. Socialno-ekonomicheskie nauki. No. 12, pp. 103-119. 
Neklyudov E.G. (2020). Gornozavodskaya promyshlennost v Rossii vtoroy poloviny XIX nachala XX v.: vybor organizacionnoy modeli [The Mining Industry in Russia of the Second Half of the $19^{\text {th }}-$ Early $20^{\text {th }}$ Ccenturies: the Choice of an Organizational Model]. In Uralskiy istoricheskiy vestnik. No. 1 (66), pp. 93-102.

Rogers, R.P. (2009). An Economic History of the American Steel Industry. New York, Routledge. 224 p.

Sigov, S.P. (1936). Ocherki po istorii gornozavodskoy promyshlennosti Urala [Essays of the History of the Mining Industry of the Urals]. Sverdlovsk, Sverdlgiz. 292 p.

Smirnov, A.P. (Ed.). (1959). Ocherki po istorii Bashkirskoj ASSR: v 2 t. [Essays on the History of the Bashkir ASSR]. Ufa, Bashknigoizdat. Vol. 1, Iss. 2. 539 p.

Strumilin, S.G. (1967). Izbrannye proizvedeniya: Istoriya chernoy metallurgii $v$ SSSR [Selected Works: The History of Ferrous Metallurgy in the USSR]. Moscow, Nauka. 442 p.

(1995). The World Book Encyclopedia. Chicago, A Scott Fetzer company. Vol. 10. 478 p.

Vasilevskiy, V.S. (1932). Zlatoust. Proshloe i nastoyashchee zavodov [Zlatoust. Past and Present of Factories]. Leningrad, Komintern. 70 p.

Vyatkin, M.P. (1965). Gornozavodskoy Ural v 1900-1917 gg. [Mining Ural in 1900-1917]. Moscow, Leningrad. 400 p.

Статья поступила в редакцию 15.03.2021 г. 